\title{
WATER QUALITY INDEX WITH MISSING PARAMETERS
}

\author{
Garima Srivastava ${ }^{1}$, Pradeep Kumar ${ }^{2}$ \\ ${ }^{1}$ M.Tech (Environmental Science \& Engg.), ${ }^{2}$ Associate Professor, Civil Engg Department, HBTI Kanpur, India \\ mailtorumi@gmail.com,pkt2001@rediffmail.com
}

\begin{abstract}
This paper presents the efficient modifications in calculating formula of water quality index. Water quality index provides us a single number which expresses overall water quality at a certain location and time which is based on several quality parameters. The objective of an index is to turn complex water quality data into information that is understandable and usable by the public.

In this paper a formula will be found to calculate water quality index when the numerical value of some of it's quality parameters are missing. The standard formula to calculate water quality index has nine water quality parameters-biochemical oxygen demand, dissolved oxygen, $\mathrm{pH}$, nitrate, phosphate, faecal coliform, turbidity, total dissolve solids and temperature. Sometimes it becomes very difficult to find out the values of all these parameters because of lack of time or because of failure in testing. In that case the formula with missing parameters will help us to calculate water quality index.
\end{abstract}

Index Terms: Water quality index, q-values, weight factors, weighted mean.

$* * *$

\section{INTRODUCTION}

The index is basically a mathematical means of calculating a single value from multiple test results. The index result represents the level of water quality in a given water basin, such as a lake, river, or stream. It is important to monitor water quality over a period of time in order to detect changes in the water's ecosystem. The Water Quality Index can give an indication of the health of the watershed at various points and can be used to keep track of and analyze changes over time. The WQI can be used to monitor water quality changes in a particular water supply over time or it can be used to compare a water supply's quality with other water supplies in the region or from around the world.

The WQI is one of the most widely used of all existing water quality procedures. The overall results of nine separate tests can be used to determine if a particular stretch of river is healthy.

The WQI consists of nine tests:

- Dissolved Oxygen

- Fecal Coliform

- $\mathrm{pH}$

- $\quad$ BOD (Biochemical Oxygen Demand)

- Temperature

- Total Phosphate

- Nitrates

- Turbidity

- Total Solids

After completing the nine tests, the results are recorded and transferred to a weighting curve chart where a numerical value is obtained. For each test, the numerical value or Q-value is multiplied by a "weighting factor." For example, dissolved oxygen has a relatively high weighting factor (.17); because it is more significant in determining water quality than the other tests. The nine resulting values are then added to arrive at an overall water quality index (WQI). The highest score a body of water can receive is 100 .

Table1- Water Quality Ranges

\begin{tabular}{|l|l|}
\hline Index Ranges & Water Quality \\
\hline $0-25$ & Very bad \\
\hline $25-50$ & Bad \\
\hline $50-70$ & Medium \\
\hline $70-90$ & Good \\
\hline $90-100$ & Excellent \\
\hline
\end{tabular}

\section{PARTS OF WATER QUALITY INDEX}

There are two parts of water quality index.

- Q- value

- Weighting factor

\subsection{Q- value}

It is the indication of water quality relative to 100 of one parameter. The Q-Value is an indication of how good (or bad) the water quality is relative to one parameter.

- $100=$ Very Good

- 1 = Very Bad 


\subsection{Weighting Factor}

It sets the relative importance of the parameter to over all water quality.

Table2- weighing factors of water quality parameters

\begin{tabular}{|l|l|}
\hline Parameters & Weight Factors \\
\hline DO & 0.17 \\
\hline FAECAL COLIFORM & 0.16 \\
\hline BOD & 0.11 \\
\hline $\mathrm{pH}$ & 0.11 \\
\hline NITRATE & 0.10 \\
\hline PHOSPHATE & 0.10 \\
\hline TEMPRATURE & 0.10 \\
\hline TURBIDITY & 0.08 \\
\hline $\begin{array}{l}\text { TOTAL DISSOLVED } \\
\text { SOLIDS }\end{array}$ & 0.07 \\
\hline
\end{tabular}

\section{PARAMETERS OF WATER QUALITY INDEX}

There are nine parameters of water quality index:

\subsection{Biochemical Oxygen Demand}

The Biochemical Oxygen Demand or BOD is a measure of the amount of food for bacteria which is found in water. Bacteria utilize organic matter in their respiration and remove oxygen from the water. The BOD test provides a rough idea of how much biodegradable waste is present in the water. Biodegradable waste is usually composed of organic wastes including leaves, grass clippings, and manure. It is expressed in $\mathrm{mg} / \mathrm{l}$.

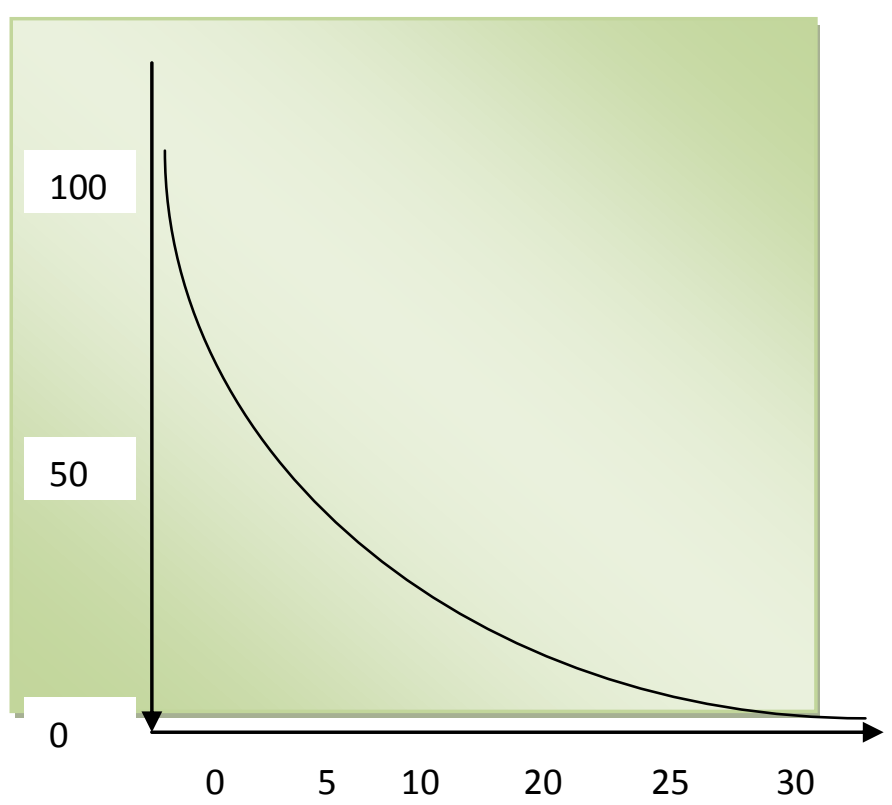

Graph 1: Relation between BOD \& q-value
This graph shows the relation between biochemical oxygen demand at x-axis and it's q- value at y-axis. It is clear from the graph that if the value of biochemical oxygen demand is increased then it's q- value will be decreased. If the value of biochemical oxygen demand exceeds $30 \mathrm{mg} / \mathrm{l}$ then the q-value for it will be taken as 2.0.

\subsection{Dissolved Oxygen}

The dissolved oxygen test measures the amount of life-sustaining oxygen dissolved in the water. This is the oxygen that is available to fish, invertebrates, and all other animals living in the water. Most aquatic plants and animals need oxygen to survive in fact fish will drown in water when the dissolved oxygen levels get too low. Low levels of dissolved oxygen in water are a sign of possible pollution. It means if a water body has high value of dissolved oxygen in it then the water quality is considered good with respect to it's dissolved oxygen's value. On the other hand if a water body has low value of dissolved oxygen in it then the water quality is considered as bad with respect to it's dissolved oxygen's value.

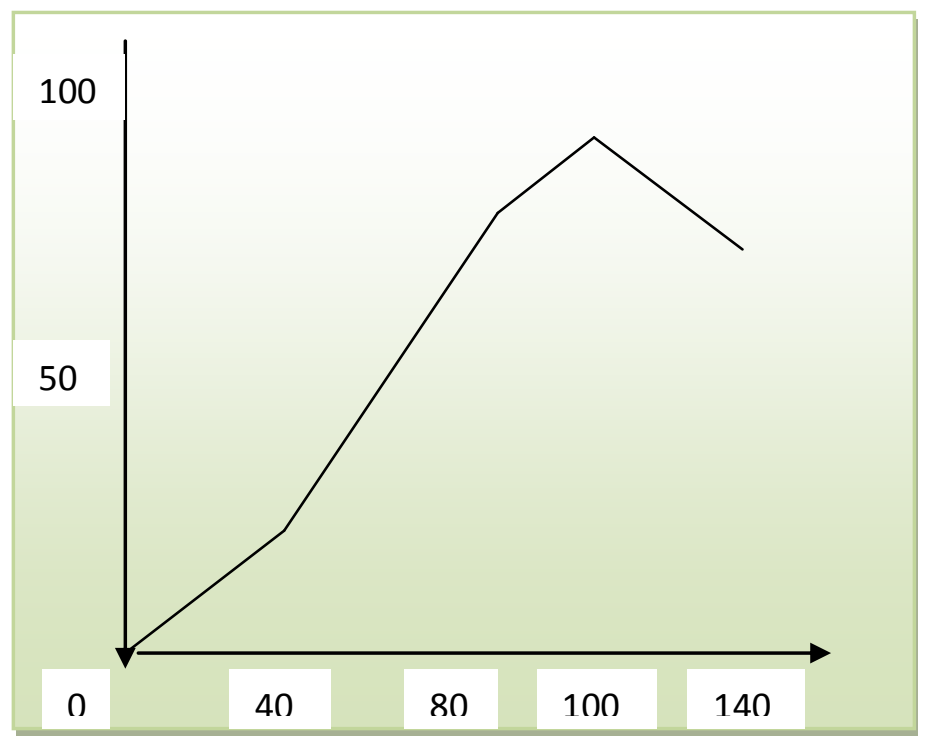

Graph 2: Relation between DO \& q-value

This graph shows thre relation between $\%$ saturation of dissolved oxygen at x-axis and it's q-value at y-axis.It is clear from the graph that if the value of dissolved oxygen is increased then it's q- value also increases upto a saturation value. After this saturation value, the q- value decreases with increase in dissolved oxygen. If \% saturation exceeds 140 then q-value is taken as 50 .

\subsection{Fecal Coliform}

Fecal coliform is a form of bacteria found in human and animal waste. 


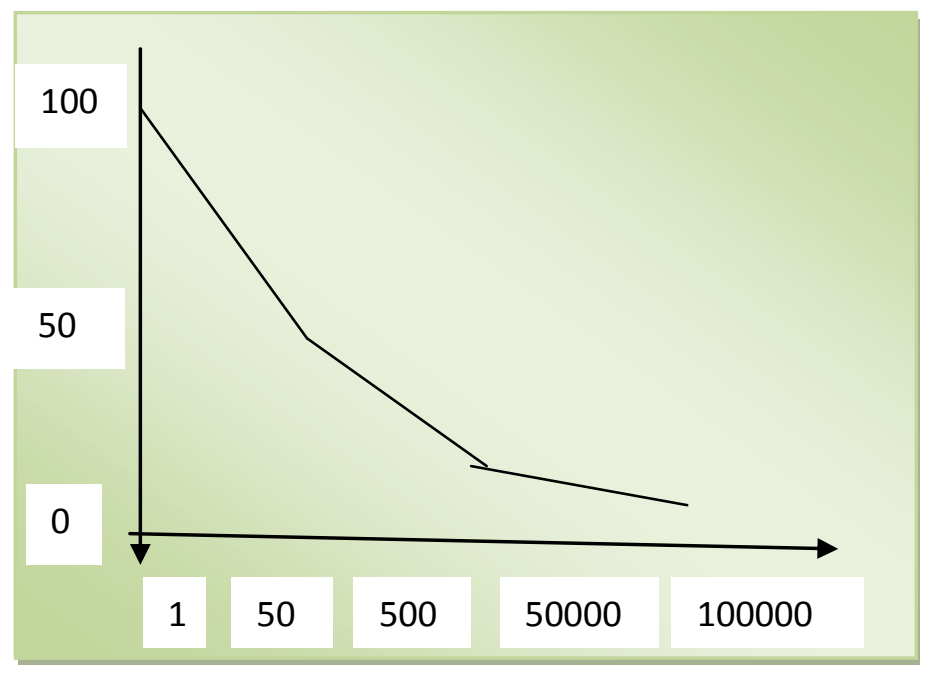

Graph 3: Relation between FC \& q-value

This graph shows the relation between number of bacteria per $100 \mathrm{ml}$ of water at x-axis and it's q-value at y-axis. As the number of colonies of bacteria increases in a water body, it's qvalue decreases means increase in bacteria makes the water quality poor. Fecal coliform is measured as number of bacteria in per hundred mili litre of water. If number of bacteri exceeds 100000 then q-value is taken as 2 .

\subsection{Nitrate}

Nitrates are a measure of the oxidized form of nitrogen and are an essential macronutrient in aquatic environments. Nitrates can be harmful to humans, because our intestines can break nitrates down into nitrites which affect the ability of red blood cells to carry oxygen. Nitrites can also cause serious illnesses in fish.

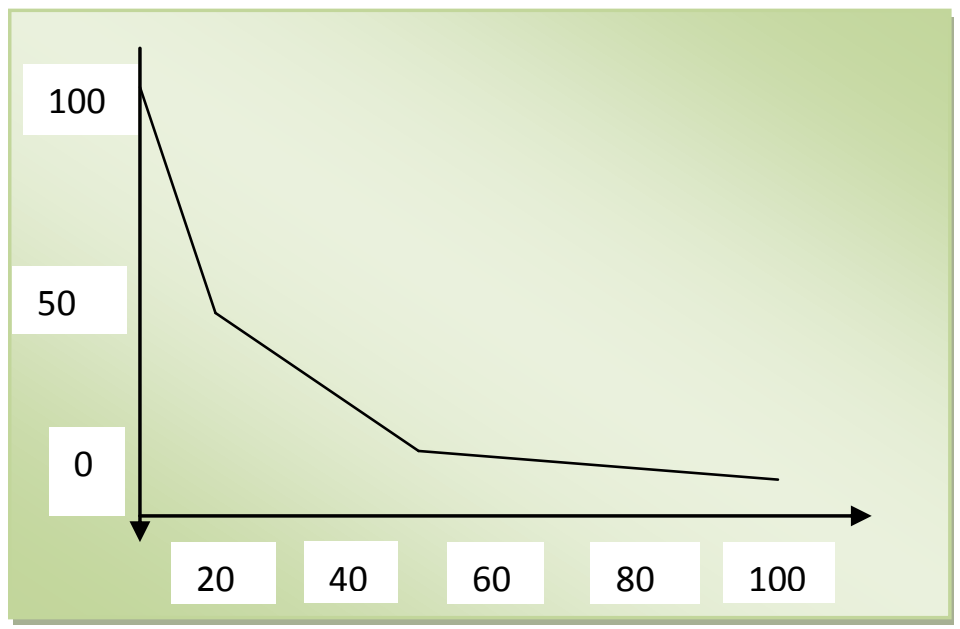

Graph 4: Relation between nitrate \& q-value
This graph shows the relation between nitrate content in water at $\mathrm{x}$-axis and it's q- value at y-axis. Upto $10 \mathrm{mg} / \mathrm{l}$, a sudden decrease is seen in the $\mathrm{q}$-value. After this upto $50 \mathrm{mg} / \mathrm{l}$. the $\mathrm{q}$ value decrease with a comparatively lower rate and $50 \mathrm{mg} / \mathrm{l}$ the rate of change in $\mathrm{q}$-value with nitrate becomes very slow. If nitrate value is greater than $100 \mathrm{mg} / \mathrm{l}$ then q-value is taken as 1 .

\section{$3.5 \mathrm{pH}$}

The $\mathrm{pH}$ level is a measure of the acid content of the water. Most forms of aquatic life tend to be very sensitive to $\mathrm{pH}$. Water containing a great deal of organic pollution will normally tend to be somewhat acidic. Water with a $\mathrm{pH}$ of 7 is considered neutral. If the $\mathrm{pH}$ is below 7, it is classified as acidic, while water with a $\mathrm{pH}$ greater than 7 is said to be alkaline.

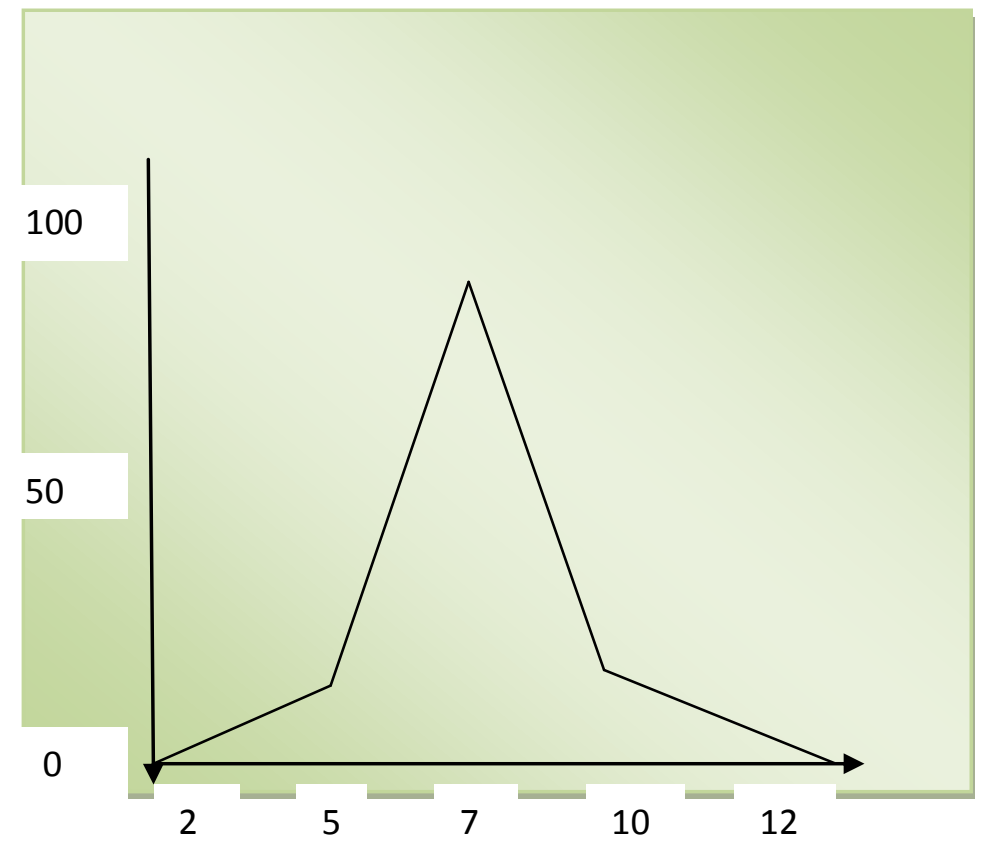

Graph 5: Relation between $\mathrm{pH} \& \mathrm{q}-\mathrm{value}$

This graph shows the relation between $\mathrm{pH}$ at $\mathrm{x}$-axis and it's qvalue at $\mathrm{y}$ - axis. The q- value is maximum at a $\mathrm{pH}$ value of 7 . As the $\mathrm{pH}$ value increases or decreases the value is decrease in both the cases. Means water quality is best when it is neutral. If $\mathrm{pH}$ is less than 2 or greater than 12 then it's q-value is taken as 0 .

\subsection{Temperature}

The water temperature of a river is very important, as many of the physical, biological, and chemical characteristics of a river are directly affected by temperature. Most waterborne animal and plant life survives within a certain range of water temperatures, and few of them can tolerate extreme changes in this parameter. Using the same thermometer, the water temperature should be checked at the test site and at a similar site one mile upstream. Care should be taken when taking the temperature upstream to ensure that the amount of sunlight and the depth of the river are 
similar to the original test site.

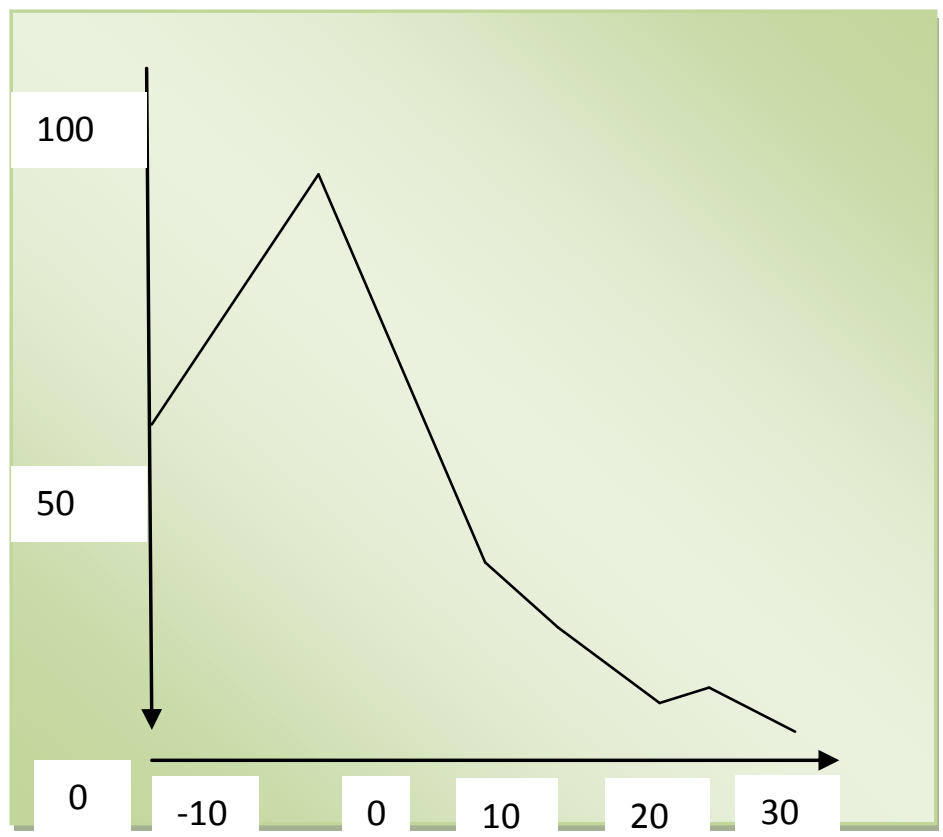

Graph 6: Relation between temprature \& q-value

This graph shows the relation between temprature of a water body at $\mathrm{x}$-axis and it's q- value at y-axis. At zero degree celsius, the q- value is maximum. If the temprature of water body increases, it's q- value decreases and if the temprature goes below the freezing point then also the q-value decreases.

\subsection{Total Dissolved Solids}

This is a measure of the solid materials dissolved in the river water. This includes salts, some organic materials, and a wide range of other things from nutrients to toxic materials. A constant level of minerals in the water is necessary for aquatic life. Concentrations of total dissolved solids that are too high or too low may limit growth and lead to the death of many aquatic life.

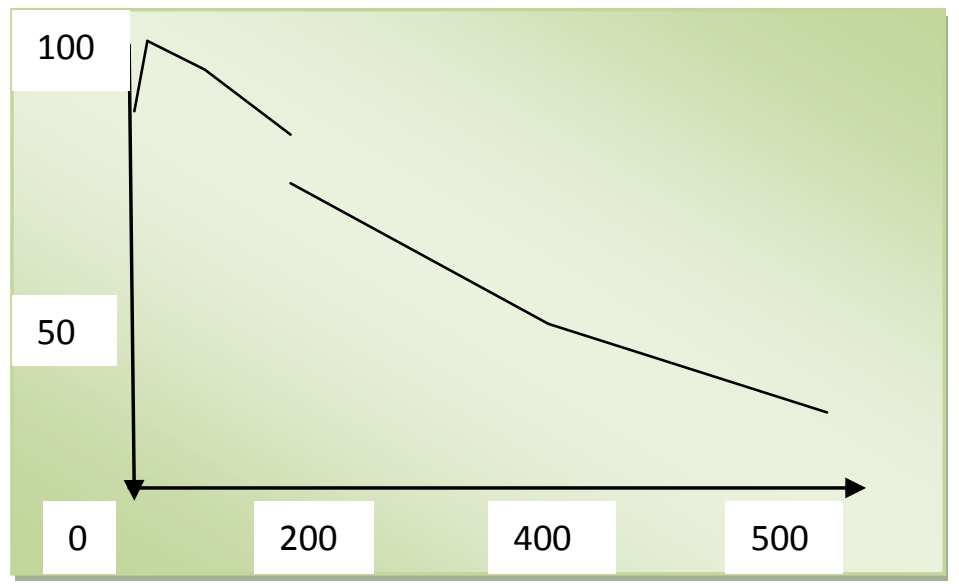

This graph shows the relation brtween total dissolved solids at $\mathrm{x}$ axis and it's q-value at y-axis. Upto $50 \mathrm{mg} / \mathrm{l}$ of TDS, the q-value increses with increases with increse in it but after $50 \mathrm{mg} / \mathrm{l}$, the qvalue decreases. If TDS value exceeds $500 \mathrm{mg} / \mathrm{l}$, the q- value os taken as 20 for higher values.

\subsection{Phosphate}

Phosphates are chemical compounds made from the elements phosphorous and oxygen; they are necessary for plant and animal growth. Phosphates can be present in water in many forms, so total phosphate gives an estimate of the total amount of phosphate potentially available in a given water supply.

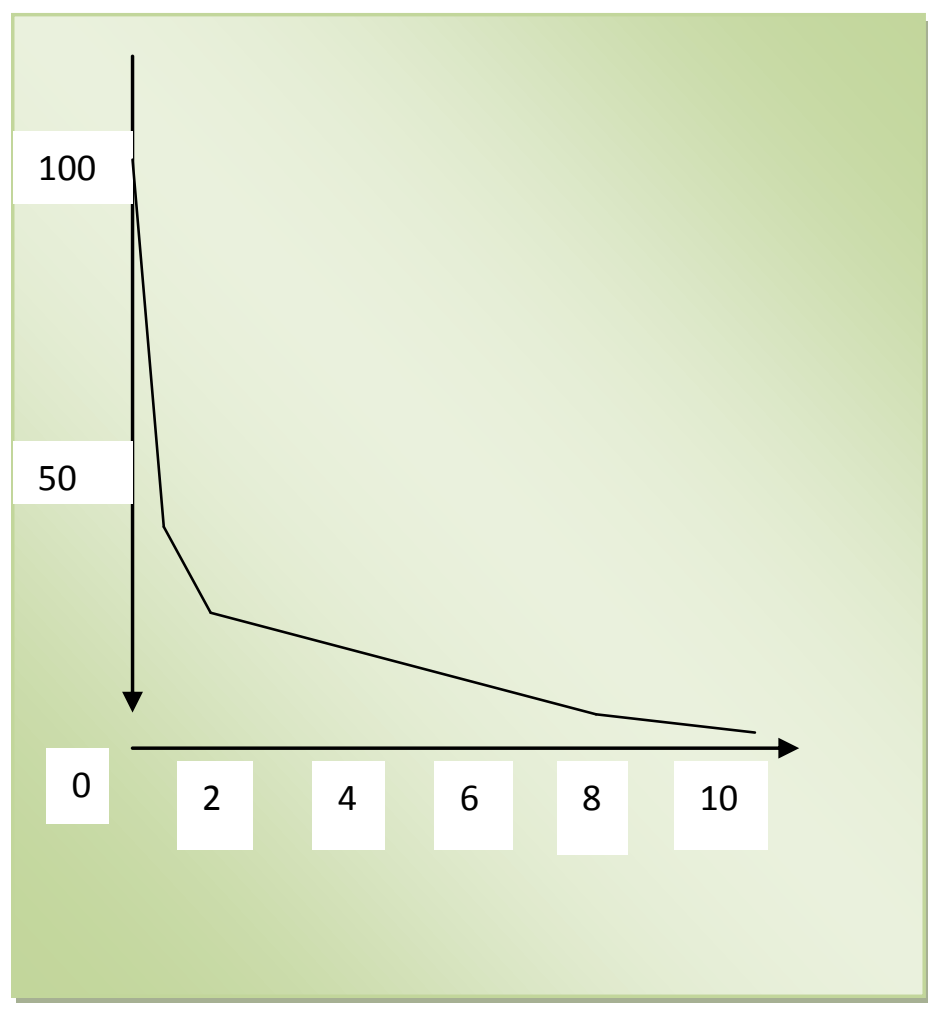

Graph 8: Relation between phosphate \& q-value

This graph shows the relation between phosphate at $\mathrm{x}$-aixs and it's q-value at y-axis. There is a sudden decrease in q-value when concentration of phosphate change from 0 to $1 \mathrm{mg} / \mathrm{l}$ and after it the q- value decreases slowly with increase in phosphate concentration. For all concentration greater than 10, the q- value is taken as 2 .

\subsection{Turbidity}

Turbidity is a measure of the dispersion of light in a column of water due to suspended matter. The higher the turbidity, the cloudier the water appears. If water becomes too turbid, it loses the ability to support a wide variety of plants and other aquatic organisms.

Graph7: Relation between TDS \& q-value 


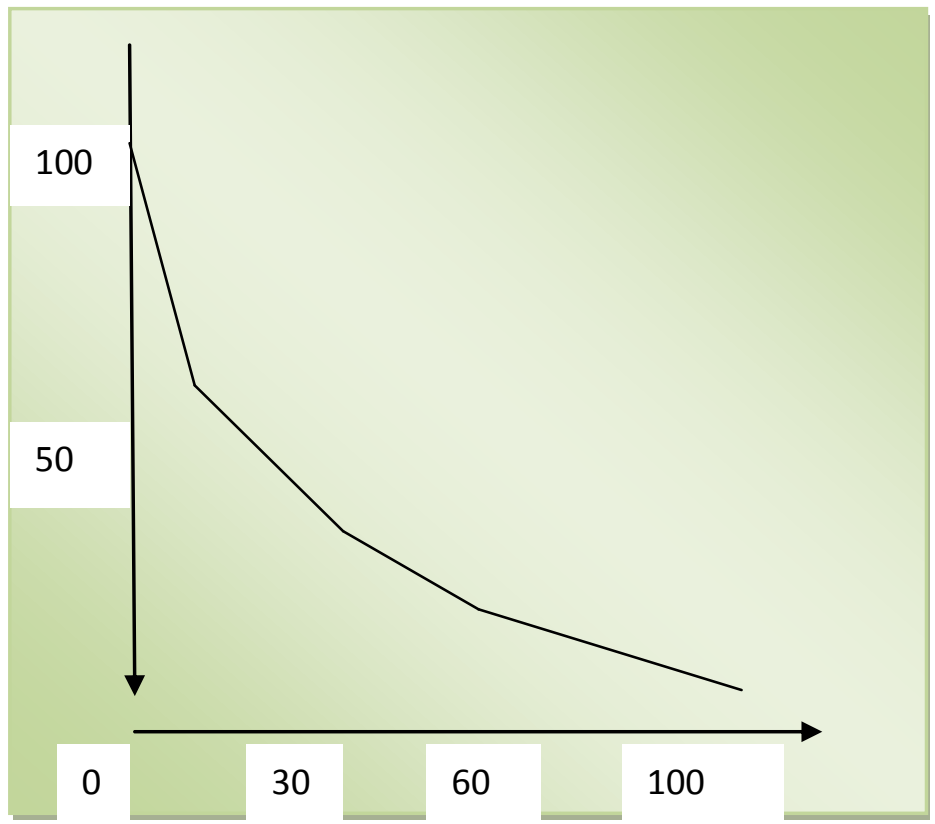

Graph 9: Relation between turbidity \& q-value

This graph shows the relation between turbidity at $\mathrm{x}$-axis and it's q- value at $y$-axis. The q- value decreases with increase in turbidity. Turbidity is expressed in NTU. For all values of turbidity greater than $100 \mathrm{NTU}$, the q- value is taken as 5 .

\section{CALCULATION OF WATER QUALITY INDEX}

The standard formula to calculate water quality index is :

$$
\begin{aligned}
\mathrm{WQI} & =\sum \mathrm{W}_{\mathrm{X}} \mathrm{Q}_{\mathrm{X}} \\
& =\mathrm{W}_{\mathrm{BOD}} \mathrm{Q}_{\mathrm{BOD}}+\mathrm{W}_{\mathrm{DO}} \mathrm{Q}_{\mathrm{DO}}+\mathrm{W}_{\mathrm{PH}} \mathrm{Q}_{\mathrm{PH}}+
\end{aligned}
$$

$\mathrm{W}_{\text {PHOSPhATE }} \mathrm{Q}_{\text {PhOSPhATE }}+\mathrm{W}_{\text {NITRATE }} \mathrm{Q}_{\text {NITRATE }}+\mathrm{W}_{\mathrm{FC}} \mathrm{Q}_{\mathrm{FC}}+$ $\mathrm{W}_{\text {TDS }} \mathrm{Q}_{\mathrm{TDS}}+\mathrm{W}_{\text {TEMP. }} \mathrm{Q}_{\text {TEMP. }}+\mathrm{W}_{\text {TURBIDITY }} \mathrm{Q}_{\text {TURBIDITY }}$

\section{Here,}

$\mathrm{W}_{\mathrm{X}}=$ weight factors of the water quality parameters

$\mathrm{Q}_{\mathrm{X}}=\mathrm{q}$ - value of the water quality parameters

$\mathrm{X}=$ water quality parameters

It is the standatrd formula to calculate WQI and gives best result. But to calculate water quality index using this equation we must know the concentration of all nine parameters.

\section{CALCULATION OF WQI WITH MISSING PARAMETERS}

Although the standard formula to calculate water quality index gives the best result but sometimes it is difficult to get the concentration of all nine quality parameters because of lack of time or testing failure. To overcome this problem, we can get an equation by using which we can calculate water quality index without having the concentration of all parameters.
In this case when concentrations of some parameters are not available, first we can calculate the q- values of those parameters, the concentration of which is available and then those q- values are multiplied with their respective weighting factors. Now the summation of these values are taken and then divided by the summation of weighting factors of available parameters.

The equation can be given as:

$$
\mathrm{WQI}_{\mathrm{MP}}=\sum \mathrm{W}_{\mathrm{Y}} \mathrm{Q}_{\mathrm{Y}} / \sum \mathrm{W}_{\mathrm{Y}}
$$

Here,

$\mathrm{Y}=$ available parameters

$\mathrm{Q}_{\mathrm{Y}}=\mathrm{q}$ - values of available parameters

$\mathrm{W}_{\mathrm{Y}}=$ weighting factors of available parameters

This equation would give result almost close to the result obtained by the standard equation. It means, if all nine parameters are available and we calculate water quality index by using standard equation will give almost same result as if we calculate water quality index in the absence of some parameters by using the above equation. It means, if water quality index calculated by standard equation says that water quality of any area or water body is 'medium', then water quality index calculated by above equation will also say that water quality of that area is 'medium'.

This can be best understood by taking an example:

We can take an example of river 'Ganga' in 'Bithoor' in 'Kanpur'. The data for Bithoor is:

\begin{tabular}{|l|l|l|}
\hline PARAMETERS & CONCENTRATION & Q-VALUE \\
\hline BOD & $3 \mathrm{mg} / \mathrm{l}$ & 73 \\
\hline DO & $77 \mathrm{mg} / \mathrm{l}$ & 83 \\
\hline Faecal Coliform & $3375 \mathrm{colonies} / 100 \mathrm{ml}$ & 20 \\
\hline Nitrate & $0.7 \mathrm{mg} / \mathrm{l}$ & 98 \\
\hline $\mathrm{pH}$ & 8.1 & 84 \\
\hline Phosphate & $0.3 \mathrm{mg} / \mathrm{l}$ & 80 \\
\hline Temprature & $23.7 \mathrm{degree}$ Celsius & 18 \\
\hline Turbidity & $25 \mathrm{NTU}$ & 55 \\
\hline TDS & $136 \mathrm{mg} / \mathrm{l}$ & 79 \\
\hline
\end{tabular}

First let us calculate water quality index with standard equation:

$$
\begin{gathered}
\mathrm{WQI}=\sum \mathrm{W}_{\mathrm{X}} \mathrm{Q}_{\mathrm{X}} \\
=73 * 0.11+83 * 0.17+20 * 0.16+98 * 0.10+84 * 0.11 \\
+80 * 0.10+18 * 0.10+55 * 0.08+79 * 0.07 \\
\mathrm{WQI}=64.51
\end{gathered}
$$

This result concludes that water quality of river Ganga in Bithoor is "medium". 
Now let us calculate water quality index by using second equation with BOD as missing parameter:

$$
\begin{aligned}
\mathrm{WQI}_{\mathrm{MP}} & =\sum \mathrm{W}_{\mathrm{Y}} \mathrm{Q}_{\mathrm{Y}} / \sum \mathrm{W}_{\mathrm{Y}} \\
& =(20 * 0.16+98 * 0.10+84 * 0.11+80 * 0.10+
\end{aligned}
$$$$
18 * 0.10+55 * 0.08+79 * 0.07+83 * 0.17) /(0.16+0.10+0.11
$$$$
+0.10+0.10+0.08+0.07+0.17)
$$

$$
\mathrm{WQI}_{\mathrm{MP}}=63.02
$$

Although the result is different from the first result but the difference is very less and can be avoided as we can see, in both the cases the water quality of river Ganga in Bithoor is 'medium'

\section{CONCLUSIONS}

Thus it can be concluded that the equation to calculate water quality index with missing parameters is very useful when it is difficult to find the concentration of all nine quality parameters.

\section{ACKNOWLEDGEMENTS}

First and above all, I would like to thank God, the almighty for providing me this opportunity.

I feel great pleasure in expressing my deep sense of gratitude, obligation and heartiest respect to Pradeep Kumar, Department of Civil Engg. for his kind support, meticulous guidance and heart touching inspirations throughout this paper work.

I gratefully acknowledge the blessings and valuable suggestions from all faculty members of the department especially Dr. D. L. Parmar, Dr. Deepesh Singh and Prof. Sunil Kumar.

I am thankful to the authorities of Central Library, HBTI Kanpur, for permitting me to consult the library.

I take this opportunity to express my thanks and gratitude to my parents and my friends for their never ending affection and encouragement.

\section{REFERENCES:}

[1]. National sanitation foundation

[2]. www.water-research.net

[3]. www.waterontheweb.org

\section{BIOGRAPHIES:}

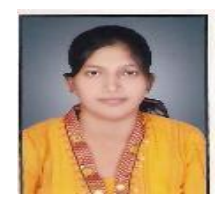

Garima Srivastava, M. Tech.(Environmental science \& engg.), HBTI Kanpur, Uttar Pradesh(India)

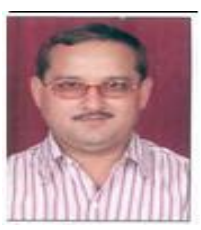

Pradeep Kumar, Associate Professor, Department of Civil Engg., HBTI Kanpur, Uttar Pradesh(India) 